\title{
The Nexus of Greenhouse Gas Emissions and Agriculture Sector: Case of Turkey and China
}

\author{
Hasan Gökhan Doğan ${ }^{1, a, *}$, Güngör Karakaş̧,b \\ ${ }^{1}$ Department of Agricultural Economics, Faculty of Agriculture Kırşehir Ahi Evran University, 40100 Kırşehir, Turkey \\ ${ }^{2}$ Vocational School of Social Sciences, Hitit University, 19030 Çorum, Turkey
}

*Corresponding author

\begin{tabular}{|c|c|}
\hline A R T I C L E I F O & A B S T R A C T \\
\hline $\begin{array}{l}\text { Keywords: } \\
\text { Agricultural policy } \\
\text { Agricultural } \mathrm{CO}_{2} \\
\text { Greenhouse effect } \\
\text { Agriculture } \\
\text { Turkey }\end{array}$ & $\begin{array}{l}\text { Greenhouse gas emissions constitute the basis of global warming. One of the sectors contributing to } \\
\text { the greenhouse gas emissions is the agriculture sector which accounts for } 24 \% \text { of the global } \\
\text { greenhouse gas emissions. In this study, the effect of cattle husbandry, small ruminant husbandry, } \\
\text { poultry husbandry, paddy production, which are the main causes of emissions in the agriculture } \\
\text { sector, on agricultural } \mathrm{CO}_{2} \text { release was investigated. The research covers the years } 1991-2017 \text { of } \\
\text { Turkey and China. In the study, time-series analyses such as Augmented Dickey-Fuller Breakpoint } \\
\text { Unit Root Test, Johansen Cointegration Test, Ordinary Least Square Regression, Full Modified } \\
\text { Ordinary Least Square, Canonical Cointegrating Regression and Impulse-Response Analysis were } \\
\text { used. According to the results of the analysis, the effects of cattle husbandry, small ruminant } \\
\text { husbandry, and paddy production activities on agricultural } \mathrm{CO}_{2} \text { emissions were statistically } \\
\text { significant in Turkey. We determined that the most effective variable on agricultural CO emissions } \\
\text { was cattle husbandry both in the long- and short-term. On the other hand, poultry farming had no } \\
\text { statistically significant effect on agricultural CO emissions. According to the results of the analysis } \\
\text { for China, all variables were statistically significant. As a result, it is important to adopt methods } \\
\text { that will not cause environmental damage or will have minimal impact in determination processes } \\
\text { of effective parameters on agricultural } \mathrm{CO}_{2} \text {. The government should determine the boundaries of } \\
\text { agricultural production processes through legal arrangements and the relevant ministries should } \\
\text { implement them seriously. To take these measures and implement them are seen as a necessity for a } \\
\text { sustainable world and a sustainable agricultural sector. }\end{array}$ \\
\hline
\end{tabular}

\section{Introduction}

Greenhouse gas emissions increase can be observed significantly from the industrial revolution to the present day (Dellal, 2008). According to the report of the International Panel on Climate Change (IPCC) in 2013, the world average surface temperature (land and sea) has risen by $0.85^{\circ} \mathrm{C}$ from the industrial revolution to the present day, and if measures are not taken on this subject, it will increase by $1.8-4.0^{\circ} \mathrm{C}$ at the end of the century (IPCC, 2014). The report highlights human-based activities as a primary cause of climate change. Although there is a causal relationship between climate change and global warming, the main point of origin is that the density of greenhouse gases released into the atmosphere is too high. For this reason, different initiatives are made to show holistic efforts on a global scale to keep atmospheric greenhouse gas concentrations at a certain level (Bayraç and Doğan,
2016). According to some projections, it is estimated that an ecosystem region of $10 \%$ will be affected by a temperature rise of around $1-2^{\circ} \mathrm{C}$ on earth in the future as a result of the greenhouse effect. In addition, estimates that forest fires will be inevitable and insect infestation will be a part of life are increasing day by day. Similarly, streams, lakes and sea creatures can be adversely affected by the process. If the temperature rise becomes more than $1-2^{\circ} \mathrm{C}$, it is expected that $15-20 \%$ of ecosystem areas will change worldwide. If the temperature rises above $2{ }^{\circ} \mathrm{C}$, it is estimated that more than $20 \%$ of the world's ecosystem will be influenced (Doğan and Tüzer, 2011).

Global warming and climate change have an important impact on the economies of developed and developing countries. It can be said that these economic impacts will reach a great extent unless necessary emission reduction 
and adaptation measures are taken. According to the calculations on the economic effects of this process, the economic cost of a $1^{\circ} \mathrm{C}$ increase in global warming is estimated to be 2 trillion dollars per year after 2050 . According to a study conducted in the EU, the cumulative global economic cost of global warming was revealed as 74 trillion euros (Bayraç and Doğan, 2016). In terms of economic impacts, there are many sectors directly linked to global warming. Although these sectors contribute to greenhouse gas emissions in a variety of ways, the agricultural sector can be assessed in a separate category. Agriculture is an industry that both increases emissions and reduces the impact of emissions. Direct greenhouse gas emissions in agriculture are caused by soil and animals during agricultural production processes, inorganic fertilizers, and agricultural chemicals, and fossil fuels used to supply energy needs in the sector.

Mitigation and adaptation policies against climate change and its adverse effects on agriculture are being implemented by international climate organizations (Akalin, 2014; Peker et al., 2019). Turkey strives to combat climate change, in a number of national plans, programs, and strategies, especially in the development plans. In particular, many policies and measures have been implemented in energy, agriculture, forestry, transport, industry, and waste sectors. Turkey is obliged to prepare national declarations of climate change every four years under the UN Framework Convention on Climate Change. Finally, the 6th Report on the National Climate Change was prepared. The report addresses the greenhouse gas emissions and inventory of absorber areas, the policies, and measures to reduce gas emissions, greenhouse gas projections and mitigation scenarios, climate change impacts and adaptation, financial resources required for measures to be taken, transfer of technology, educationtraining activities for public awareness. The report focused on the agricultural sector with sensitivity among the issues that could be affected by the climate change in Turkey. Accordingly, emission reduction adaptation policies were proposed. The organization responsible for combating climate change in Turkey is the Ministry of Agriculture and Forestry. The ministry has many projects, strategies and policies related to agriculture. (Dellal et al., 2015).

Since various greenhouse gases are emerging as a result of agricultural activities (energy consumption, animal husbandry, paddy production, fertilization, and spraying etc.), agricultural production is one of the main causes of climate change. Today, with the increase of meat-dairy cattle husbandry, poultry raising, and dairy industry, there is a significant increase in environmental pollution caused by animal production enterprises (Demir and Cevger, 2007). Agriculture sector contributes approximately half of the anthropogenic $\mathrm{CH}_{4}$ emissions at the global level (Karakurt et al., 2012) out of which rice paddy fields contribute about $20 \%$ (Ke et al., 2014). Animal husbandry is one of the greatest sources of human-induced greenhouse gas emissions (Casey and Holden, 2005). It accounts for about $14.5 \%$ of all human-induced greenhouse gas emissions in the World (FAO, 2014).

In the agricultural sector, applications such as animal waste and stomach fermentation, paddy production, irrigation, improper land use and soil processing, fertilization, energy use are the main sources of emissions. Enteric fermentation (47\%), agricultural soils (40\%) and manure management $(11 \%)$ are effective in greenhouse gases production in Turkey (IPM, 2017). Greenhouse gas emissions in the world are caused by industry (21\%), transport (14\%), buildings (6\%), agriculture-forestry and other land use (24\%), electricity and heat production (25\%) and other energy production applications (10\%) (IPCC 2014; Figure 1).

China is one of the world's largest greenhouse gas emissions countries. In this study, some parameters contributing to the agricultural emissions in Turkey and China were investigated. While agriculture contributes to anthropogenic emissions as a holistic, the revelation of the contribution of the dynamics within itself is important in terms of the precautions to be taken. A study on climate change and agriculture in Turkey shows that the economic impact of climate change will not reach serious dimensions until the late 2030s, but negative impacts will affect the economy in the second half of this century (Dudu and Çakmak, 2018). According to these findings, there is enough time for Turkey to take measures. It is very important to determine atmospheric greenhouse gas concentrations for sustainable agriculture and environment, to achieve mitigation of methane emissions, to keep them at a certain level (Bayraç and Doğan, 2016). For this reason, it is necessary to make studies and predictions on climate change and agriculture in Turkey.

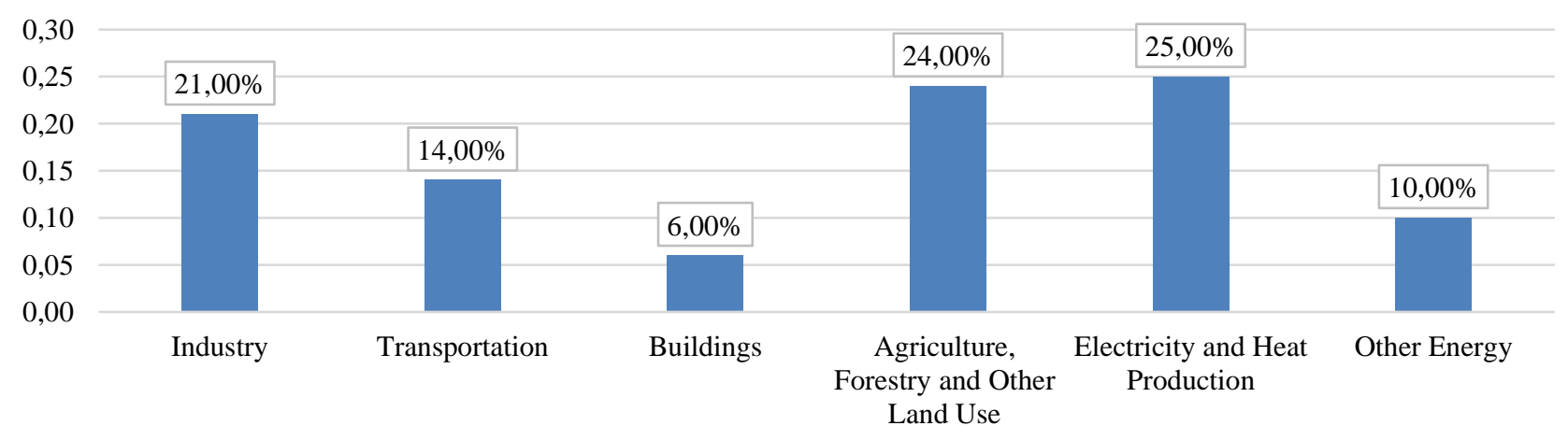

Figure 1 Sectoral Greenhouse Emission (Reference: IPCC, 2014) 
In the literature, the effects of agricultural production on $\mathrm{CO}_{2}$ emissions in both short term and long term were investigated with relevant econometric models. In Pakistan, the effect of forest and agricultural production on $\mathrm{CO}_{2}$ emission was investigated. In the study, which are relevant econometric techniques, Autoregressive Distributed Lag model (ARDL), FMOLS, DOLS, and VECM were used. As a result of the research, agricultural production positively and significantly affects $\mathrm{CO}_{2}$ emission in the long run which implies that agriculture production is also a major carbon source in Pakistan (Waheed et al., 2018). A study was conducted in the EU28 countries and the causality relationship between climate change and agricultural yields was investigated. As a result of the research, a negative bidirectional relationship between climate change and agricultural yields was verified (Agovino et al., 2018). Another study in Pakistan, the relationship between agricultural value-added, vegetable field and greenhouse gas emissions was investigated in Pakistan. VECM, FMOLS, CCR techniques were used in the study. There was the long run causality of GHG emission, agriculture value added, and forest area. It was emphasized that the way to decrease greenhouse gas was increased in agricultural value added, renewable energy, vegetable area and forest area (Khan et al., 2018). Doğan and Kan (2018) studied that the relation between the change in the greenhouse gas emission, which is the most important factor of global warming (as a $\mathrm{CO}_{2}$ equivalent) and the change in population, GDP, energy use and agricultural fields in Turkey through a time-series analysis. Doğan and Kan (2019) investigated the effect of the changes in temperature and precipitation in Turkey between 1997 and 2016 on wheat yield by using panel FMOLS and panel VECM analysis.

Although the effect of agricultural activities on greenhouse gas emissions is known, it is important to determine their rates within the agricultural sector. To achieve this, the dependent variable $\mathrm{CO}_{2}$ was chosen as the indicator of greenhouse gas emission and the independent variables were selected as number of cattle, number of small ruminants, number of poultry, and paddy production areas. The purpose of the selection of these econometric techniques was to determine the effect of main emission sources, which includes the number of cattle, number of small ruminants, number of poultry, and paddy production fields on $\mathrm{CO}_{2}$ emissions.

\section{Material and Method}

In this study, time series analyses were used. The research covers the years 1991-2017 of Turkey and China. The main parameters selected from the agricultural sector in Turkey and China were included in the study. These are the number of cattle, the number of small ruminants, the number of poultry, the cultivation area of paddy crops, and the level of agricultural $\mathrm{CO}_{2}$ (Table 1).

Table 1 shows a $30.52 \%$ increase in cattle number, a $140.01 \%$ increase in poultry number, a $171.19 \%$ increase in paddy cultivation area and a $27.24 \%$ increase in agricultural $\mathrm{CO}_{2}$ emissions in Turkey compared to 1991 . Although the number of small ruminants decreased by $13.45 \%$, it has increased since the mid-2000's. The symbols and data sources representing agricultural $\mathrm{CO}_{2}$ levels, number of cattle, number of small ruminants, number of poultry, and paddy production areas are given in Table 2 according to the years. In China, there are a $2.49 \%$ increase in cattle, a $167.04 \%$ increase in small ruminants, a $115.51 \%$ increase in poultry, a $21.76 \%$ increase agricultural $\mathrm{CO}_{2}$ and a $6.00 \%$ decrease paddy cultivate area.

In the study, the annual values of the variables were converted to logarithmic form and evaluated logarithmically. The functional relationship between the variables used in the research can be expressed as in Equation 1;

$$
\ln \ddot{Y}=f\left(\ln \chi_{1}, \ln \chi_{2}, \ln \chi_{3}, \ln \chi_{4}\right)
$$

Based on this functional relationship, a series of econometric analyses were used to investigate the effects of the variables on agricultural $\mathrm{CO}_{2}$.

These can be listed as;

- Augmented Dickey-Fuller Breakpoint Unit RootTest

- Johansen Cointegration test

- Ordinary Least Square Regression

- Full Modified Ordinary Least Square

- Canonical Cointegrating Regression

- Impulse-Response Analysis

\section{Augmented Dickey-Fuller Test (ADF Breakpoint Unit} Root Test)

Augmented Dickey-Fuller Test is carried out to investigate the state of stationary in series. This can be explained as being affected by the past values of the series. In such a case, the problem of spurious regression can be encountered and the results cannot be considered as real results (Maddala and Shaowen, 1999; Kao and Chiang, 2000; Hadri, 2000; Choi, 2001; Levin et al., 2002; Im et al., 2003). The basic assumption of the Augmented Dickey-Fuller Test is based on the ADF principle. However, there may be periodic breaks in some series. Ignoring structural breaks in the short and long term can lead to significant statistical problems. Therefore, ADF Structural Breakpoint Unit Root Test was used in the study. Other structural breakpoint unit root tests have developed different strategies by adding dummy variables to the ADF test. The notation for the ADF Breakpoint Unit Root Test, which is the basis of these strategies, can be expressed as follows (Perron, 1989);

$$
\Delta \mathrm{X}_{\mathrm{t}}=\widehat{\delta} \Delta \mathrm{Z}_{\mathrm{t}}+\beta_{\mathrm{i}} \mathrm{X}_{\mathrm{t}-1}+\sum_{\mathrm{j}=1}^{\mathrm{k}} \theta_{\mathrm{i}} \Delta \mathrm{X}_{\mathrm{t}-\mathrm{j}}+\mathrm{e}_{\mathrm{t}}
$$

In Equation 2, $\hat{\delta}$ is obtained from regression on $\Delta \mathrm{Z}_{\mathrm{t}}$ of $\Delta \mathrm{X}_{\mathrm{t}}$. k; lag length and $\mathrm{e}_{\mathrm{t}}$; stochastic term. $\sum_{\mathrm{j}=1}^{\mathrm{k}} \theta_{\mathrm{i}} \Delta \mathrm{X}_{\mathrm{t}-\mathrm{j}}+\mathrm{e}_{\mathrm{t}}$ is included in the model to solve the autocorrelation problem in ADF approach (Çağlar, 2015). Classic ADF test statistic results were compared with Mac Kinnon critical value and accepted or rejected at the $\% 1, \% 5$, and $\% 10$ significance level (MacKinnon, 1996). ADF Structural Breakpoint Unit Root Test results were assessed by Vogelsang p-value (Perron and Vogelsang, 1993). Lag lengths were determined by the automatic selection criterion and this criterion was determined as the lag length which gives the lowest AIC/SIC value. 
Table 1 Animal number, paddy cultivation area and agricultural $\mathrm{CO}_{2}$ trend*

\begin{tabular}{|c|c|c|c|c|c|}
\hline Years & $\begin{array}{l}\text { Cattle } \\
\text { (head) }\end{array}$ & $\begin{array}{l}\text { Small Ruminant } \\
\text { (head) }\end{array}$ & $\begin{array}{c}\text { Poultry } \\
\text { (head) }\end{array}$ & $\begin{array}{l}\text { Paddy } \\
\text { (da) }\end{array}$ & $\begin{array}{l}\text { Agricultural CO2 } \\
\text { (million tons) }\end{array}$ \\
\hline \multicolumn{6}{|c|}{ in Turkey (1991-2017) } \\
\hline 1991 & 12.339 .073 & 51.196 .538 & 145.050 .726 & 404.000 & 45.82 \\
\hline 1992 & 12.303 .317 & 49.869 .878 & 158.770 .084 & 430.000 & 46.06 \\
\hline 1993 & 12.226 .000 & 47.674 .000 & 184.459 .780 & 448.500 & 46.76 \\
\hline 1994 & 12.206 .000 & 45.210 .000 & 190.033 .022 & 405.000 & 44.04 \\
\hline 1995 & 12.044 .000 & 42.902 .000 & 135.250 .515 & 500.000 & 43.35 \\
\hline 1996 & 12.121 .000 & 42.023 .000 & 158.756 .285 & 548.500 & 44.19 \\
\hline 1997 & 11.379 .000 & 38.614 .000 & 175.223 .388 & 550.000 & 42.15 \\
\hline 1998 & 11.207 .000 & 37.492 .000 & 243.913 .791 & 600.000 & 43.74 \\
\hline 1999 & 11.219 .000 & 38.030 .000 & 246.476 .193 & 650.000 & 44.36 \\
\hline 2000 & 10.907 .000 & 35.693 .000 & 264.450 .658 & 580.000 & 42.50 \\
\hline 2001 & 10.686 .000 & 33.994 .000 & 223.140 .518 & 590.000 & 39.84 \\
\hline 2002 & 99.245 .75 & 31.953 .800 & 251.100 .958 & 600.000 & 37.96 \\
\hline 2003 & 99.01 .458 & 32.203 .214 & 283.674 .374 & 650.000 & 41.15 \\
\hline 2004 & 10.173 .246 & 31.811 .092 & 302.799 .483 & 700.000 & 42.23 \\
\hline 2005 & 10.631 .405 & 31.821 .789 & 322.917 .207 & 850.000 & 43.34 \\
\hline 2006 & 10.971 .880 & 32.260 .206 & 349.402 .117 & 991.000 & 44.80 \\
\hline 2007 & 11.121 .458 & 31.748 .651 & 273.548 .489 & 939.000 & 44.38 \\
\hline 2008 & 10.946 .239 & 29.568 .152 & 249.043 .739 & 995.000 & 42.15 \\
\hline 2009 & 10.811 .165 & 26.877 .793 & 234.082 .206 & 967.541 & 43.36 \\
\hline 2010 & 11.454 .526 & 29.382 .924 & 238.972 .961 & 990.000 & 45.78 \\
\hline 2011 & 12.483 .969 & 32.309 .518 & 241.498 .538 & 994.000 & 48.15 \\
\hline 2012 & 14.022 .347 & 35.782 .519 & 257.505 .341 & 1.197 .247 & 53.77 \\
\hline 2013 & 14.532 .848 & 38.509 .795 & 270.202 .034 & 1.105 .924 & 57.20 \\
\hline 2014 & 14.344 .935 & 41.485 .180 & 298.029 .734 & 1.108 .844 & 57.23 \\
\hline 2015 & 14.127 .837 & 41.924 .100 & 316.332 .446 & 1.158 .561 & 57.42 \\
\hline 2016 & 14.222 .228 & 41.329 .232 & 333.541 .262 & 1.160 .563 & 57.80 \\
\hline 2017 & 16.105 .025 & 44.312 .308 & 348.143 .754 & 1.095 .599 & 58.30 \\
\hline \multicolumn{6}{|c|}{ in China (1991-2017) } \\
\hline Years & $\begin{array}{l}\text { Cattle } \\
\text { (head) }\end{array}$ & $\begin{array}{l}\text { Small Ruminant } \\
\text { (head) }\end{array}$ & $\begin{array}{c}\text { Poultry } \\
\text { (1000 head) }\end{array}$ & $\begin{array}{l}\text { Paddy } \\
\text { (da) }\end{array}$ & $\begin{array}{c}\text { Agricultural CO2 } \\
\text { (tons) }\end{array}$ \\
\hline 1991 & 81.327 .882 & 112.816 .397 & 2.307 .975 & 33.018 .802 & 5.610 .805 .857 \\
\hline 1992 & 82.722 .948 & 110.855 .419 & 2.443 .192 & 32.487 .358 & 5.659 .727 .563 \\
\hline 1993 & 85.783 .320 & 109.719 .499 & 2.696 .795 & 30.745 .927 & 5.532 .651 .966 \\
\hline 1994 & 90.908 .312 & 111.618 .616 & 3.002 .174 & 30.537 .237 & 5.725 .443 .394 \\
\hline 1995 & 100.555 .931 & 117.444 .851 & 3.137 .449 & 31.107 .479 & 6.300 .853 .117 \\
\hline 1996 & 108.913 .232 & 127.263 .462 & 3.474 .548 & 31.753 .892 & 6.709 .888 .045 \\
\hline 1997 & 90.835 .401 & 114.125 .387 & 3.983 .955 & 32.129 .200 & 6.074 .935 .205 \\
\hline 1998 & 99.435 .292 & 120.956 .205 & 3.120 .365 & 31.571 .500 & 6.272 .060 .728 \\
\hline 1999 & 101.912 .343 & 127.352 .236 & 3.422 .110 & 31.637 .100 & 6.461 .855 .566 \\
\hline 2000 & 104.553 .559 & 131.095 .105 & 3.623 .012 & 30.301 .490 & 6.341 .845 .235 \\
\hline 2001 & 100.929 .433 & 130.026 .217 & 3.769 .485 & 29.144 .019 & 6.242 .368 .406 \\
\hline 2002 & 95.555 .476 & 130.628 .215 & 4.098 .910 & 28.508 .800 & 6.327 .566 .765 \\
\hline 2003 & 93.099 .589 & 133.997 .215 & 3.980 .546 & 26.780 .124 & 6.227 .838 .217 \\
\hline 2004 & 92.207 .458 & 143.395 .215 & 4.214 .648 & 28.615 .715 & 6.403 .920 .571 \\
\hline 2005 & 90.134 .331 & 152.305 .215 & 4.445 .244 & 29.116 .400 & 6.479 .354 .448 \\
\hline 2006 & 87.548 .391 & 151.337 .213 & 4.451 .868 & 29.201 .080 & 6.504 .797 .198 \\
\hline 2007 & 82.066 .855 & 146.018 .206 & 4.711 .583 & 29.179 .116 & 6.433 .376 .911 \\
\hline 2008 & 82.815 .275 & 142.282 .208 & 5.030 .399 & 29.493 .392 & 6.547 .507 .555 \\
\hline 2009 & 82.624 .651 & 128.557 .214 & 5.222 .198 & 29.881 .590 & 6.624 .350 .631 \\
\hline 2010 & 83.798 .151 & 134.021 .218 & 5.302 .720 & 30.117 .262 & 6.724 .577 .063 \\
\hline 2011 & 83.023 .758 & 138.840 .219 & 4.710 .988 & 30.311 .295 & 6.714 .314 .652 \\
\hline 2012 & 80.402 .985 & 139.615 .720 & 4.916 .571 & 30.397 .873 & 6.743 .138 .028 \\
\hline 2013 & 80.328 .809 & 143.680 .040 & 4.835 .178 & 30.581 .915 & 6.770 .584 .199 \\
\hline 2014 & 80.652 .987 & 150.017 .440 & 4.632 .640 & 30.580 .921 & 6.790 .422 .821 \\
\hline 2015 & 82.265 .743 & 158.490 .235 & 4.701 .235 & 31.035 .861 & 6.862 .217 .499 \\
\hline 2016 & 84.523 .349 & 162.062 .714 & 5.046 .404 & 31.019 .837 & 6.909 .583 .147 \\
\hline 2017 & 83.355 .177 & 301.267 .113 & 4.973 .912 & 31.035 .820 & 6.831 .854 .740 \\
\hline
\end{tabular}

\footnotetext{
*Source: World bank Statistic, 2019.
} 
Table 2 Variables, symbols and data sources used in research*

\begin{tabular}{l|cl}
\hline \multicolumn{1}{c|}{ Variables } & Symbols & \multicolumn{1}{c}{ Unit } \\
\hline Agricultural $\mathrm{CO}_{2}$ & $\ddot{\mathrm{Y}}$ & Million tons of oil equivalent (Turkey) Tons (China) \\
Total number of cattle & $\chi_{1}$ & head \\
Total number of sheep and goat & $\chi_{2}$ & Head (Turkey), 1000 Head (China) \\
Total poultry number & $\chi_{3}$ & Head \\
Total paddy planting area & $\chi_{4}$ & Head \\
\hline
\end{tabular}

*Source: World Bank, TURKSTAT, FAO

\section{Johansen Cointegration Test}

The test was developed by Johansen (1988) to investigate whether the series was cointegrated in the longterm. Test notations are given in equation 3.4;

$$
\begin{aligned}
& \mathrm{Y}_{\mathrm{t}}=\sum_{\mathrm{i}=1}^{\mathrm{p}} \mathrm{A}_{\mathrm{i}} \mathrm{Y}_{\mathrm{t}-\mathrm{i}}+\beta \mathrm{X}_{\mathrm{t}}+\mathrm{e}_{\mathrm{t}} \\
& \Delta \mathrm{Y}_{\mathrm{t}}=\pi \mathrm{Y}_{\mathrm{t}-1}+\sum_{\mathrm{i}=1}^{\mathrm{p}-1} \delta_{\mathrm{i}} \mathrm{Y}_{\mathrm{t}-\mathrm{i}}+\beta \mathrm{X}_{\mathrm{t}}+\mathrm{v}_{\mathrm{t}}
\end{aligned}
$$

In Equation 3, the dependent and independent variables are series that are static at the same level (unlike the level I(0)). If the series are made stationary at the same level (I(1) level) and the notation is re-expressed, the equation 4 is obtained. Here is expressed as $\pi=\alpha \beta$. $\alpha$ and $\beta$ denote the two matrices in the notation (Göçer et al., 2013; Akpolat and Altıntaş, 2013). $\alpha$ represents adaptation rate, and $\beta$ represents the matrix of long-term cointegration coefficients (Tarı, 2010).

\section{Ordinary Least Square Regression}

The so-called Ordinary Least Square (OLS) method was introduced by Galton (1886). With the solution of the model, the partial effects of the independent variables on the dependent variable are calculated, and the model adapted to this study is expressed in Equation 5.

$$
\ddot{Y}_{t}=\beta_{1} \chi_{1}+\beta_{2} \chi_{2}+\beta_{3} \chi_{3}+\beta_{4} \chi_{4}+e_{t}
$$

Here, $\beta_{1 \ldots 4}$ represents the coefficients of the independent variables, also $e_{t}$ represents the error term with a normal distribution.

\section{Full Modified Ordinary Least Square}

The Full Modified Ordinary Least Square (FMOLS) test was developed by Pedroni (Pedroni, 2000; 2001). The FMOLS test, which is used to investigate long-term relationships, can fix problems such as autocorrelation and heteroscedasticity in many ways (Gülmez and Yardımcıoğlu, 2012). Here, the FMOLS test can be solved with the help of equality $6,7,8,9$, based on the assumption that the $\mathrm{T}$ statistic is normally distributed;

$$
\begin{aligned}
& \ddot{\mathrm{Y}}_{\mathrm{NT}}^{*}=\mathrm{N}^{-1} \sum_{\mathrm{i}=1}^{\mathrm{N}}\left[\sum_{\mathrm{t}=1}^{\mathrm{T}}\left(\chi_{1_{\mathrm{t}}}-\overline{\chi_{\mathrm{i}}}\right)^{2}\right]^{-1}\left[\sum_{\mathrm{t}=1}^{\mathrm{T}}\left(\chi_{\mathrm{l}_{\mathrm{t}}}-\overline{\chi_{\mathrm{i}}}\right) \ddot{\mathrm{Y}}_{\mathrm{t}}^{*}-\mathrm{T} \hat{\tau}_{\mathrm{i}}\right] \\
& \ddot{\mathrm{Y}}_{\mathrm{NT}}^{*}=\mathrm{N}^{-1} \sum_{\mathrm{i}=1}^{\mathrm{N}}\left[\sum_{\mathrm{t}=1}^{\mathrm{T}}\left(\chi_{2_{\mathrm{t}}}-\overline{\chi_{2}}\right)^{2}\right]^{-1}\left[\sum_{\mathrm{t}=1}^{\mathrm{T}}\left(\chi_{2_{\mathrm{t}}}-\overline{\chi_{\mathrm{z}_{\mathrm{i}}}}\right) \ddot{\mathrm{Y}}_{\mathrm{t}}^{*}-\mathrm{T} \hat{\tau}_{\mathrm{i}}\right] \\
& \ddot{\mathrm{Y}}_{\mathrm{NT}}^{*}=\mathrm{N}^{-1} \sum_{\mathrm{i}=1}^{\mathrm{N}}\left[\sum_{\mathrm{t}=1}^{\mathrm{T}}\left(\chi_{3_{\mathrm{t}}}-\overline{\chi_{\mathrm{i}}}\right)^{2}\right]^{-1}\left[\sum_{\mathrm{t}=1}^{\mathrm{T}}\left(\chi_{3_{\mathrm{t}}}-\overline{\chi_{\mathrm{i}}}\right) \ddot{\mathrm{Y}}_{\mathrm{t}}^{*}-\mathrm{T} \hat{\tau}_{\mathrm{i}}\right] \\
& \ddot{\mathrm{Y}}_{\mathrm{NT}}^{*}=\mathrm{N}^{-1} \sum_{\mathrm{i}=1}^{\mathrm{N}}\left[\sum_{\mathrm{t}=1}^{\mathrm{T}}\left(\chi_{\psi_{\mathrm{t}}}-\overline{\chi_{4_{\mathrm{i}}}}\right)^{2}\right]^{-1}\left[\sum_{\mathrm{t}=1}^{\mathrm{T}}\left(\chi_{4_{\mathrm{t}}}-\overline{\chi_{\mathrm{i}}}\right) \ddot{\mathrm{Y}}_{\mathrm{t}}^{*}-\mathrm{T} \hat{\tau}_{\mathrm{i}}\right]
\end{aligned}
$$

\section{Canonical Cointegrating Regression}

Canonical Cointegrating Regression (CCR) developed by Park (1992), can eliminate deviations in the OLS technique. In this context, long-term covariance matrix transformations of variables are used. The goal is to eliminate problems caused by correlation in the long-term (Mehmood et al., 2014). Although there are many aspects that resemble the FMOLS test, the use of static data conversions in CCR technique reveals the distinction between them (Park, 1992).

\section{Impulse-Response Analysis}

The Impulse-Response Analysis is used to measure the response of the variables in the model to a one-unit shock (Enders, 1995). The shock that a variable is exposed to affects not only that variable, but also all other variables due to the structure of the VAR model. As a result, some projections can be developed for determining how other variables react in the face of sudden policy changes or different shocks. According to Brooks (2008), IRF follows the shocks of the dependent variables in the model to other variables. For each variable in each individual equation, a unit shock is applied to the term of the error and its effects on the VAR system are determined over time. Thus, if there is $\mathrm{x}$ number of variables in the system, an impulse-response up to X2 occurs in total. (Lütkepohl and Saikkonen, 1997).

\section{Empirical Results}

The results of the Augmented Dickey-Fuller Breakpoint Unit Root Test (ADF) for the variables are given in Table 3.

When examined Table 3, for Turkey, according to Intercept contains unit root at I (0) level total agricultural $\mathrm{CO}_{2}$, total number of cattle, total number of small ruminants and total number of poultry. Total paddy crop cultivation area is stationary at I (0) level. Total agricultural $\mathrm{CO}_{2}$, total number of poultry and total paddy crop cultivation areas were determined to be stationary at I (1) level. According to Trend and Intercept, while all of the variables were include unit root in I (0) level, all variable were stationary at I(1) level. For China, according to Intercept contains unit root at $\mathrm{I}(0)$ small ruminant, poultry and paddy production. According to trend and intercept contains unit root at $\mathrm{I}(0)$ level total agricultural $\mathrm{CO}_{2}$ and cattle. According to both Intercept and Trend and Intercept no contains unit root I(1) level all variables. After, Johansen Cointegration Analysis was made with stationary series. Results were given Table 4.

Table 4 shows that two cointegration vectors are determined among the variables according to the Johansen Cointegration analysis results for Turkey. $r=0$ and $r=4$ 
vectors were statistically significant at level $1 \%$ according to Trace Statistic and at level 5\% according to the Maximum Eigenvalue statistic. For China, three cointegration vectors are determined among the variables according to the Johansen Cointegration analysis results. $\mathrm{r}=0, \mathrm{r}=1$ and $\mathrm{r}=2$ vectors were statistically significant at level $1 \%$ and $5 \%$. It can be said that variables are cointegrated in the long-term. The results of OLS, FMOLS, and CCR analysis are given in Table 5 that displays the direction and intensity of these variables in the short- and long-term.

Table 5 shows the effects of the total number of cattle, total number of small ruminants, total number of cattle and total paddy cultivation areas on the dependent variable of agricultural $\mathrm{CO}_{2}$, depending on the results of OLS, FMOLS and CCR test for both Turkey and China. The results of the diagnostic test show that all the assumptions are normally determined (normality, autocorrelation, and heteroscedasticity) and that the determination coefficient indicates the existence of a strong correlation both in the short- (OLS) and long-term (FMOLS and CCR). The most effective variable on agricultural $\mathrm{CO}_{2}$ is the total number of cattle both in the long- and short-term. This is followed by the total number of small ruminants and the size of the total paddy fields. As a result of the analysis, there was no significant correlation between the number of poultry and agricultural $\mathrm{CO}_{2}$ for Turkey. In China, all variables are statistically significant. The most effective variables on agricultural $\mathrm{CO} 2$ are paddy cultivation areas and poultry.

Another dimension of the study is the ImpulseResponse analysis. The impulse-response functions reflect the effect of a standard deviation shock on the present and future values of the internal variables in one of the random error terms. In addition, it provides an idea of the use of the influential variable as a policy tool (Özsoy, 2009). In Figure 2, the responses of agricultural $\mathrm{CO}_{2}$ against one-unit shock in the variables used in the study were expressed visually.

$\underline{\text { Table } 3 \text { Augmented Dickey-Fuller Breakpoint Unit Root Test (ADF) results for variables }}$

\begin{tabular}{|c|c|c|c|c|}
\hline \multirow{3}{*}{ Variables } & \multicolumn{4}{|c|}{ ADF Breakpoint Unit Root Test (For Turkey) } \\
\hline & \multicolumn{2}{|c|}{ Intercept } & \multicolumn{2}{|c|}{ Trend and Intercept } \\
\hline & $\mathrm{I}(0)$ & $\mathrm{I}(1)$ & $\mathrm{I}(0)$ & $\mathrm{I}(1)$ \\
\hline$\ddot{\mathrm{Y}}$ & $-3,1639$ & $-5,6986^{*}$ & $-5,0003$ & $-5,7214^{*}$ \\
\hline$\chi_{1}$ & $-2,7309$ & $-2,6426$ & $-1,6122$ & $-4,6978 * * *$ \\
\hline$\chi_{2}$ & $-2,8014$ & $-2,4456$ & 1,1073 & $-5,2034 * *$ \\
\hline$\chi_{3}$ & $-2,6357$ & $-4,7331 * *$ & $-3,7575$ & $-5,8500 *$ \\
\hline$\chi_{4}$ & $-4,2732 * * *$ & $-5,5263 *$ & $-3,7914$ & $-6,1031 *$ \\
\hline \multirow{3}{*}{ Variables } & \multicolumn{4}{|c|}{ ADF Breakpoint Unit Root Test (For China) } \\
\hline & \multicolumn{2}{|c|}{ Intercept } & \multicolumn{2}{|c|}{ Trend and Intercept } \\
\hline & $\mathrm{I}(0)$ & $\mathrm{I}(1)$ & $\mathrm{I}(0)$ & $\mathrm{I}(1)$ \\
\hline$\ddot{\mathrm{Y}}$ & $-5,2552 *$ & $-5,8157^{*}$ & $-4,4848$ & $-7,9548 *$ \\
\hline$\chi_{1}$ & $-5,2229 *$ & $-5,6383^{*}$ & $-3,7359$ & $-8,3765^{*}$ \\
\hline$\chi_{2}$ & $-1,4887$ & $-5,7891 *$ & $-5,3165 * *$ & $-6,3462 *$ \\
\hline$\chi_{3}$ & $-2,8097$ & $-8,0707^{*}$ & $-6,0762 *$ & $-7,4112 *$ \\
\hline$\chi_{4}$ & $-2,4780$ & $-5,9383^{*}$ & $-5,7372 *$ & $-8,9553 *$ \\
\hline
\end{tabular}

Table 4 Johansen Cointegration analysis results

\begin{tabular}{|c|c|c|c|c|c|c|}
\hline \multicolumn{7}{|c|}{ Johensen Cointegration analysis results (for Turkey) } \\
\hline & \multicolumn{3}{|c|}{ Trace } & \multicolumn{3}{|c|}{ Maximum Eigenvalue } \\
\hline & $\begin{array}{l}\text { Eigen } \\
\text { value }\end{array}$ & $\begin{array}{c}\text { Trace } \\
\text { Statistic }\end{array}$ & $\begin{array}{c}0.05 \text { Critical } \\
\text { Value }\end{array}$ & $\begin{array}{l}\text { Eigen } \\
\text { value }\end{array}$ & $\begin{array}{c}\text { Max-Eigen } \\
\text { Statistic }\end{array}$ & $\begin{array}{c}0.05 \text { Critical } \\
\text { Value }\end{array}$ \\
\hline $\mathrm{r}=0$ & 0.7748 & 75.9902 & $69.8188 *$ & 0.7748 & 37.2738 & $33.8768 * *$ \\
\hline $\mathrm{r}=1$ & 0.4958 & 38.7163 & 47.8561 & 0.4958 & 17.1201 & 27.5843 \\
\hline$r=2$ & 0.3401 & 21.5962 & 29.7970 & 0.3401 & 10.3939 & 21.1316 \\
\hline$r=3$ & 0.2321 & 11.2022 & 15.4947 & 0.2321 & 6.6047 & 14.2646 \\
\hline$r=4$ & 0.1679 & 4.5974 & $3.84146^{*}$ & 0.1679 & 4.5974 & $3.8414 * *$ \\
\hline \multicolumn{7}{|c|}{ Johensen Cointegration analysis results (for China) } \\
\hline & \multicolumn{3}{|c|}{ Trace } & \multicolumn{3}{|c|}{ Maximum Eigenvalue } \\
\hline & $\begin{array}{l}\text { Eigen } \\
\text { value }\end{array}$ & $\begin{array}{c}\text { Trace } \\
\text { Statistic }\end{array}$ & $\begin{array}{c}0.05 \text { Critical } \\
\text { Value }\end{array}$ & $\begin{array}{l}\text { Eigen } \\
\text { value }\end{array}$ & $\begin{array}{l}\text { Max-Eigen } \\
\text { Statistic }\end{array}$ & $\begin{array}{c}0.05 \text { Critical } \\
\text { Value }\end{array}$ \\
\hline $\mathrm{r}=0$ & 0.9381 & 138.5245 & $69.8188 *$ & 0.9381 & 63.9923 & $33.8768 *$ \\
\hline $\mathrm{r}=1$ & 0.8119 & 74.5321 & $47.8561 *$ & 0.8119 & 38.4350 & $27.5843 *$ \\
\hline$r=2$ & 0.6287 & 36.0971 & $29.7970 *$ & 0.6287 & 22.7921 & $21.1316^{* *}$ \\
\hline$r=3$ & 0.3924 & 13.3049 & 15.4947 & 0.3924 & 11.4610 & 14.2646 \\
\hline$r=4$ & 0.0770 & 1.8439 & 3.8414 & 0.0770 & 1.84395 & 3.8414 \\
\hline
\end{tabular}


Table 5 Short- and long-term coefficients related to the variables

\begin{tabular}{|c|c|c|c|c|}
\hline \multicolumn{5}{|c|}{ Dependent variable for Turkey: $\ddot{Y}$} \\
\hline Method & Independent Variables & Coefficient & t-stat & Diagnostic Tests \\
\hline OLS & $\begin{array}{l}\chi_{1} \\
\chi_{2} \\
\chi_{3} \\
\chi_{4} \\
\mathrm{C}\end{array}$ & $\begin{array}{l}0.4499 \\
0.3091 \\
0.0444 \\
0.1842 \\
-12.233 \\
\end{array}$ & $\begin{array}{l}3.1939 * \\
2.9826 * \\
1.3861 \\
3.3729 * \\
-14.987 *\end{array}$ & $\begin{array}{l}\mathrm{R}^{2}: 0,97, \text { Ad. } \mathrm{R}^{2}: 0,96 \\
\text { F:165,91 } \\
\text { B-G LM Test: } 1,13(0,34) \\
\text { B-P-G:1,33(0,29) }\end{array}$ \\
\hline FMOLS & $\begin{array}{l}\chi_{1} \\
\chi_{2} \\
\chi_{3} \\
\chi_{4} \\
\mathrm{C}\end{array}$ & $\begin{array}{l}0.4114 \\
0.3230 \\
0.0204 \\
0.1995 \\
-11.590 \\
\end{array}$ & $\begin{array}{l}3.3898^{*} \\
3.5651^{*} \\
0.7359 \\
4.2618^{*} \\
-16.846^{*}\end{array}$ & $\begin{array}{l}\mathrm{R}^{2}: 0,97 \\
\text { Ad. } \mathrm{R}^{2}: 0,96 \\
\mathrm{~J}-\mathrm{B}: 1,57(0,45)\end{array}$ \\
\hline CCR & $\begin{array}{l}\chi_{1} \\
\chi_{2} \\
\chi_{3} \\
\chi_{4} \\
\mathrm{C}\end{array}$ & $\begin{array}{l}0.3009 \\
0.3862 \\
-0.0004 \\
0.2372 \\
-10.9990 \\
\end{array}$ & $\begin{array}{l}1.8261 * * * \\
3.4721 * \\
-0.0132 \\
3.8102 * \\
-12.1252 * \\
\end{array}$ & $\begin{array}{l}\mathrm{R}^{2}: 0,96 \\
\text { Ad. } \mathrm{R}^{2}: 0,96 \\
\mathrm{~J}-\mathrm{B}: 1,34(0,50)\end{array}$ \\
\hline \multicolumn{5}{|c|}{ Dependent variable for China: $\ddot{Y}$} \\
\hline Method & Independent Variables & Coefficient & t-stat & Diagnostic Tests \\
\hline OLS & $\begin{array}{l}\chi_{1} \\
\chi_{2} \\
\chi_{3} \\
\chi_{4} \\
\mathrm{C}\end{array}$ & $\begin{array}{l}0.2118 \\
0.2396 \\
0.2078 \\
0.4816 \\
2.7596 \\
\end{array}$ & $\begin{array}{l}4.5401 * \\
4.0694 * \\
6.8992 * \\
4.7006 * \\
1.0830\end{array}$ & $\begin{array}{l}\mathrm{R}^{2}: 0,92, \text { Ad. } \mathrm{R}^{2}: 0,90 \\
\text { F:58,80 } \\
\text { B-G LM Test: } 1,09(0,35) \\
\text { B-P-G: } 1,54(0,22)\end{array}$ \\
\hline FMOLS & $\begin{array}{l}\chi_{1} \\
\chi_{2} \\
\chi_{3} \\
\chi_{4} \\
\mathrm{C}\end{array}$ & $\begin{array}{l}0.1847 \\
0.1997 \\
0.2240 \\
0.4865 \\
3.6730 \\
\end{array}$ & $\begin{array}{l}4.2062^{*} \\
3.8634^{*} \\
7.6596^{*} \\
5.4604^{*} \\
1.6652 \\
\end{array}$ & $\begin{array}{l}\mathrm{R}^{2}: 0,89 \\
\text { Ad.R }: 0,88 \\
\mathrm{~J}-\mathrm{B}: 1,25(0,53)\end{array}$ \\
\hline CCR & $\begin{array}{l}\chi_{1} \\
\chi_{2} \\
\chi_{3} \\
\chi_{4} \\
\mathrm{C}\end{array}$ & $\begin{array}{l}0.1758 \\
0.1756 \\
0.2339 \\
0.4883 \\
4.1065\end{array}$ & $\begin{array}{l}4.2618^{*} \\
2.7837^{*} * \\
8.3504^{*} \\
5.2942^{*} \\
1.6925\end{array}$ & $\begin{array}{l}\mathrm{R}^{2}: 0,89 \\
\text { Ad.R }: 0,87 \\
\mathrm{~J}-\mathrm{B}: 2,29(0,32)\end{array}$ \\
\hline
\end{tabular}

*,**,*** are significant respectively at $1 \%, 5 \%, 10 \%$, -B-G LM test is Serial Correlation Test, -B-P-G is Heteroskedasticity Test (Breusch-PaganGodfrey), -J-B is Jarque Bera Test (Normality Test)

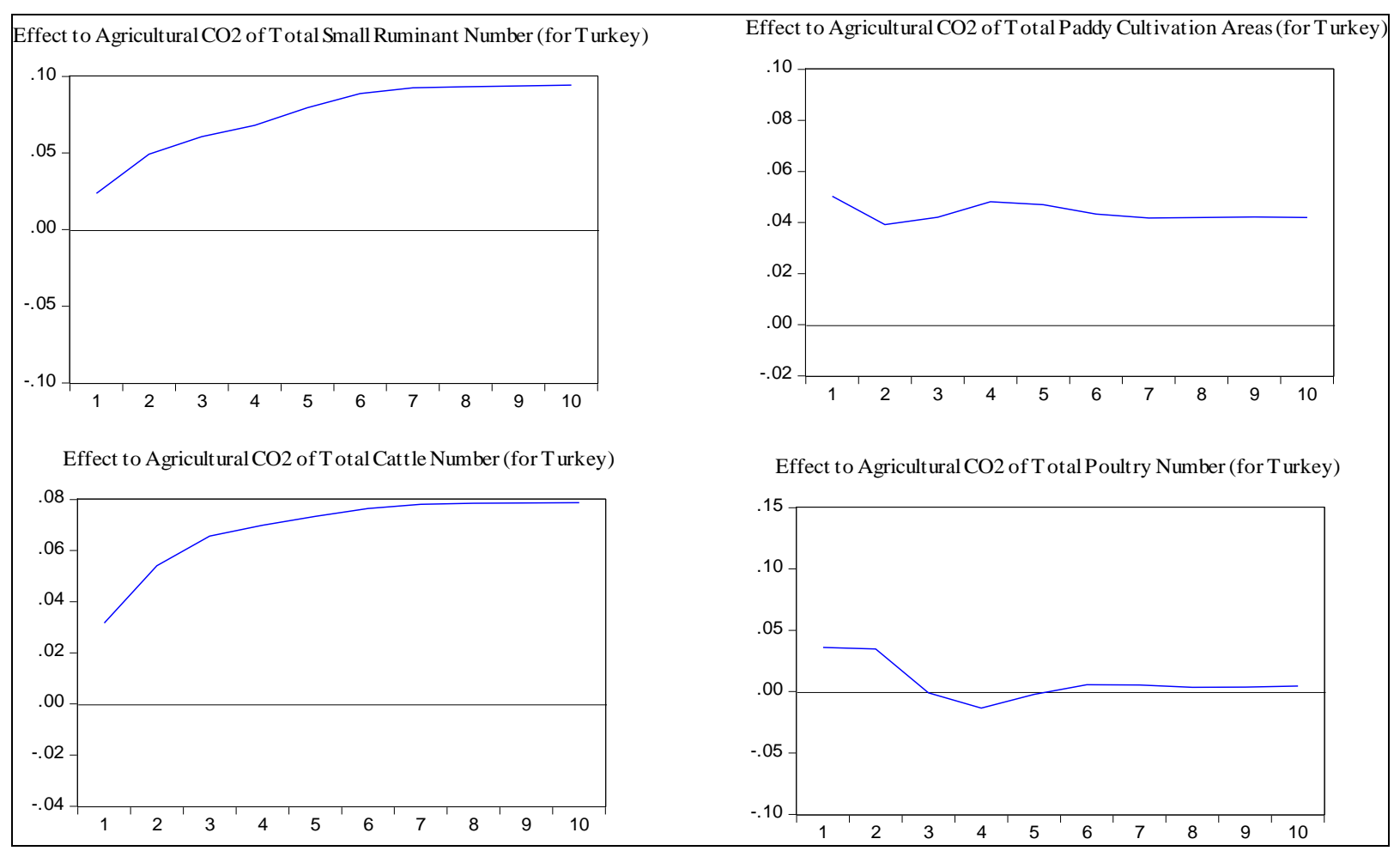

Figure 2 Graphical Results for Impulse-Response Analysis (for Turkey and China) 
Figure 2 shows an increase in agricultural $\mathrm{CO}_{2}$ levels followed by one-unit shock in the number of small animals in every term. A similar situation can be seen in the number of cattle. For the number of poultry, there is a fluctuating trend followed by a one-unit shock. However, as can be understood from the OLS and FMOLS tests, this relationship is not statistically significant. While a decrease in agricultural $\mathrm{CO}_{2}$ in the second, fifth, sixth and seventh periods of the paddy production is seen followed by one-unit shock, the increase in the ongoing periods coincides with the integrative results obtained from the study. In China, it is possible to see a fluctuating trend in all variables.

\section{Results and Discussion}

The effect of greenhouse gases on climate change is widely accepted. According to the results of the analysis, the effects of cattle husbandry, small ruminant husbandry, and paddy production activities on agricultural $\mathrm{CO}_{2}$ emissions were statistically significant. The most effective variable on agricultural $\mathrm{CO}_{2}$ emissions was determined to be the total number of cattle both in the long- and shortterm. On the other hand, the total poultry number has no effect on agricultural $\mathrm{CO}_{2}$ emissions in Turkey. In China, all variables is statistically significant. China is now the world's biggest annual emitter of greenhouse gases, with agriculture accounting for $11 \%$ of this total (Wang, Koslowski et al. 2014). Rice cultivation and livestock waste management contributed to greenhouse gas around $20 \%$ and $18 \%$, respectively in China (NCCC, 2012).

In literature, the contribution of gastric fermentation, feed, animal age, body type, animal weight and environmental stress factors to greenhouse gas emissions is mainly expressed in cattle livestock activity (Eckard, Grainger, and de Klein 2010). A previous study reported that the biggest source of greenhouse gas in animals is bovine species (Ripple et al. 2013). Ruminant production is one of the biggest greenhouse gas production sources, no matter what type of animal husbandry activity (FAO 2014). A study, conducted in India, states that the $\mathrm{CO}_{2}$ emissions of animals are 247.2 million tons (Chhabra et al., 2013). On the other hand, ammonia emerging from farm animals is said to cause global problems by causing acid rain and greenhouse effect. In particular, ruminants release greenhouse gas through their rumen fermentations during the digestive process.

The paddy which grows under water emits gas into the atmosphere throughout its production. Greenhouse gas emissions increase as paddy crop cultivation areas increase. A significant amount of water is used in rice production. Greenhouse gas emission in the atmosphere increases as fertilizer used in rice production or as it dissolves in soil of $\mathrm{CO}_{2}$ have held the soil tillage during. In the rice paddies, which are considered to be the major methane source, there is a carbon dioxide capacity of about 30 times global warming potential (Pachauri et al., 2014). Paddy crop contributes to greenhouse gas emissions and is also affected greatly both positively and negatively. In some studies, conducted in Asia, it is estimated that rice yield will decrease in the future. The reasons for this decline are the temperature changes due to global climate change and the shortening of the growing seasons. In study of (Aggarwal and Mall, 2002), it is stated that when there was no increase in $\mathrm{CO}_{2}$ level, $1^{\circ} \mathrm{C}$ increase in temperature causes average $7 \%$ yield loss, $2^{\circ} \mathrm{C}$ increase in temperature $10-16 \%$ yield loss and $4{ }^{\circ} \mathrm{C}$ increase in temperature $21-30 \%$ yield loss. Simulation studies in China indicated that rice production periods would be reduced by $100 \%$ and food safety and supply would be at a dangerous level in both the World and China (Tao et al., 2008). In a similar study, it was emphasized that according to climate scenarios product yields are average $15 \%$ uncertainty. It was concluded that the temperature will cause decrease of product yield in all regions at different levels. It is expected that $3^{\circ} \mathrm{C}$ and $6^{\circ} \mathrm{C}$ increase are cause respectively $27,9 \%$ and $55.2 \%$ decrease in hot regions (Tao et al., 2015). In study in Madagascar and Malavi of (Daccache et al., 2015), it has been determined that climate change has a positive effect on rice, comparatively. In another study, by 2050 it was predicted an increase of $8 \%$ and $5 \%$ in rice yield due to climate change (Gerardeaux et al., 2012). In another study; rice yields in West and Central Africa would be slightly decline and those in East and Southern Africa would slightly increase with climate change (Liu et al., 2008; Lobell, 2014). In another study conducted in Africa, the main reason for the decrease in yield was defined as a decrease in photosynthesis due to excessive temperature (Van Oort and Zwart, 2018). There are many factors in the literature that cause climate change. Positive or negative effects of these factors are expressed. In our study, we have revealed factors caused to increase of agricultural $\mathrm{CO}_{2}$ in Turkey that it is caused climate change. Positive or negative effects of $\mathrm{CO}_{2}$ increase have been seen in various countries of World. But what is causing these effects (which causes $\mathrm{CO}_{2}$ increase) is the basic question of our study in agricultural production. The answer to this question, it will have the right to express as cattle, small ruminant and paddy crop in Turkey conditions.

One of the issues that have caused the greenhouse gas effect and has been investigated profoundly in recent years is garbage and wastes. In literature, it is stated that in European countries, beverages and food are wasted by more than $50 \%$ of the total (Kummu et al., 2012). For America, it is stated that this value is $60 \%$ (Griffin et al., 2009). Although the results of the research in Turkey show that cattle breeding activities are causing greenhouse gas emissions, it is necessary to assess the process from consumption to production. Because the understanding of excessive consumption or consumption comprehension that is not correctly modeled increases the demand for agricultural products. This demand is reflected in production and is indirectly emerged as environmental problems. Waste causes the destruction of scarce resources, the biggest problem of mankind and the economy. As a result, while waste causes an increase in animal production, it can also contribute to the release of greenhouse gas from garbage, leading harmful results for the environment.

\section{Conclusion}

We investigated the effect of agricultural sector on greenhouse gas emissions in Turkey and China. Turkey and China were compared. The reason for this comparison, Turkey's is to determine the current situation. Because, China is one of the countries that produces the most 
greenhouse gases among the countries in the world. Cattle, small ruminant and paddy production has an impact both short term and long term on agricultural $\mathrm{CO}_{2}$ in Turkey. according to Turkey, cattle and small ruminants have less impact in China. But poultry and paddy production are more impact on agricultural $\mathrm{CO}_{2}$ (approximately double). According to Turkey, China produces excessive greenhouse gases in poultry and paddy production. According to China, Turkey produces excessive greenhouse gases in cattle and small ruminant. Both countries should take measures. The intensive farming mean that overgrazing, excessive use of fertilizers, excessive use of pesticides, excessive water consumption etc. briefly excess input-excess product is obtained. this system is very important in environmental destruction. As a result, the increase in agricultural $\mathrm{CO}_{2}$ by now is $57.3 \%$ in Turkey. It is seen that, the last 25 years in Turkey, $30.52 \%$ increased the number of cattle, $13.44 \%$ decreased the number of small ruminant, $140.04 \%$ increased the number of poultry and $171.18 \%$ increased the paddy cultivation area. Turkey government began to apply different policies in the agricultural sector in the 2000's. Agreements with international organizations such as the World Trade Organization and the EU have come to the fore. Accordingly, the practices that disrupt free market conditions have been abandoned. Instead, it has turned to practices that encourage production. Supports for deficiency payment support, input policy support, certified seed support, husbandry support and especially support for supply deficit products. As a result of this increase in production, increases were observed in environmental degradation $\left(\mathrm{CO}_{2}\right.$ emission increase, destruction of water resources, loss of workable agricultural land etc.). in our study, the findings from the results of econometric modeling support these increases. However, later measures were taken, indirectly. In Turkey, within the existing agricultural policy, there are many applications for protecting the environment such as; Supports for the Protection of Environmental Purposes Agricultural Lands, Support for Organic Agriculture, Support for Good Agricultural Practices, Biological and Biotechnical Substance Supports and laws for the protection of agricultural land. However, when the current situation is examined, it can be said that production-oriented supports and intensive agricultural practices are more than environmental support. Practices such as correct production techniques, efficient resource utilization, and equitable distribution of resources can prevent many problems in environmental issues. In particular, some legal practices and awareness raising of the producers are considered important in this process. As a result of this study, the reduction of waste caused by unbalanced consumption can be suggested as a solution.

\section{References}

Aggarwal PK, Mall RK. 2002. Climate Change and Rice Yields in Diverse Agro-Environments of India. II. Effect of Uncertainties in Scenarios and Crop Models on Impact Assessment. Climatic Change, 52(3): 331-343.

Agovino M, Casaccia M, Ciommi M, Ferrara M, Marchesano K. 2018. Agriculture, climate change and sustainability: The case of EU-28. Ecological Indicators. doi: https://doi.org/10.1016/j.ecolind.2018.04.064
Akalin M. 2014. "Effect on Agriculture of Climate Change": Adaptation and Mitigation Strategies for Eliminating These Effects. Hitit University Journal of Social Sciences Institute. Year: 7, Number: 2: 351-377. (in Turkish)

Akpolat AG, Altıntaş N. 2013. The Relationship Between Energy Consumption and Real GDP: Nexus of Cointegration and Causality. 1961-2010 Period. Journal of Knowlede Economy \& Knowledge, 8(2): 115-127. (in Turkish)

Bayraç N, Doğan E. 2016. Effect on Agriculture Sector of Climate Change in Turkey. Eskişehir Osmangazi University Journal of Economics and Administrative Sciences April, 11(1): 23- 48. (in Turkish)

Brooks C. 2008. Introductory Econometrics for Finance (Second Edition). USA:Cabridge Univerty Pres.

Casey JW, Holden NM. 2005. The relationship between greenhouse gas emissions and the intensity of milk production in Ireland. Journal of Environmental Quality, 34(2): 429-436.

Chhabra A, Manjunath KR, Panigrahy S, Parihar JS. 2013. Greenhouse gas emissions from Indian livestock. Climatic Change, 117(1), 329-344. doi: 10.1007/s10584-012-0556-8.

Choi I. 2001. Unit root tests for panel data. J Int Money Financ., 20: 249-272.

Çağlar AE. 2015. Comparison of Small Sampling Specifications The Structural Breakpoint Unit Root Tests. Pamukkale University, Institute of Social Science, Master Thesis, Econometrics Department, Turkey. (In Turkish).

Daccache A, Sataya W, Knox JW. 2015. Climate change impacts on rain-fed and irrigated rice yield in Malawi. International Journal of Agricultural Sustainability, 13(2): 87-103.

Dellal İ. 2008. "Global Climate Change and Agriculture and Food Sector in Clamp of Energy, IGEME from the point of view, Issue: 35, Ankara Province, 103-111. (in Turkish)

Dellal İ, Engürülü B, Ulukan H, Özevren AŞ, Ünal M. 2015. "Economic Reflections of Climate Change to Agricultural Sector", Turkey Agriculture Engineer VIII. Technical Congress, Full Text Book-I, Ankara Province, 62-80.

Demir P, Cevger Y. 2007. "Global Warming and Livestock Sector", Journal of Turkish Veterinary Medical Society, Volume: 78, Issue: 1: 13-16. (in Turkish)

Doğan HG, Kan A. 2019. The effect of precipitation and temperature on wheat yield in Turkey: a panel FMOLS and panel VECM approach. Environment, Development and Sustainability, 21(1): 447-460.

Doğan HG, Kan M. 2018. The Nexus of $\mathrm{CO}_{2}$ Emission, Population, Agricultural Area Size, GDP and Energy Use in Turkey. Fresenius Environmental Bulletin, 27(10): 6812-6823.

Doğan S, Tüzer M. 2011. Global climate change and its potential impacts. Cumhuriyet University Journal of Economics and Administrative Sciences, 12(1): 21-34. (in Turkish).

Dudu H, Çakmak EH. 2018. Climate change and agriculture: an integrated approach to evaluate economy-wide effects for Turkey. Climate and Development, 10(3): 275-288.

Eckard RJ, Grainger C, De Klein Cam. 2010. Options for the abatement of methane and nitrous oxide from ruminant production: A review. Livestock Science, 130(1): 47-56.

Enders W. 1995. Applied Applied Econometric Time Series. (2. ed.), New York:Jonh Wiley\&Sons. Inc.

FAO. 2014. Emissions of Greenhouse Gases from Animal Husbandry. http://www.fao.org/faostat/en/\#data/QA/visualize (Accessed on 08.07.2018)

Galton F. 1886. Family likeness in stature. Proceedings of the Royal Society of London, 40(242-245): 42-73.

Gerardeaux E, Giner M, Ramanantsoanirina A, Dusserre J. 2012. Positive effects of climate change on rice in Madagascar. Agronomy for Sustainable Development, 32(3): 619-627.

Göçer I, Mercan M, Peker O, Bulut Ş. 2013. Causes of Current Account Deficit in Turkey, Financing Quality and Sustainability: An Econometrics Analysis. Eskişehir Osmangazi University Journal of Economics and Administrative Sciences, 8(1): 213-242, (in Turkish) 
Griffin M, Sobal J, Lyson TA. 2009. An analysis of a community food waste stream. Agriculture and Human Values, 26, 6781.

Gülmez A, Yardimcioğlu F. 2012. Nexus of R \& D Expenditures and Economic Growth in OECD Countries: Panel Cointegration and Panel Causality Analysis (1990-2010). Finance Journal, 163: 335-353. (in Turkish)

Hadri K. 2000. Testing for Stationarity in Heterogeneous Panel Data. Econometric Journal, 3: 148-161.

Im K, Pesaran M, Shin Y. 2003. Testing for unit roots in heterogeneous panels. J Econom, 115: 53-74.

IPCC. 2014. The Fifth Assessment Report (AR5), The Intergovernmental Panel on Climate Change, Geneva, Switzerland. (http://www.ipcc.ch.).

IPM. 2017. İstanbul Policy Center. Strategies for Reducing the greenhouse gas emissions arising from the Agriculture Sector in Turkey. Tuğba Ağaçayak, Levent Öztürk, ISBN: 978-6059178-95-2, September 2017, Istanbul Province. (in Turkish).

Johansen S. 1988. Statistical analysis of cointegration vectors. Journal of Economic Dynamics and Control, 12(2-3): 231254.

Kao C, Chiang M. 2000. On the estimation and inference of a cointegrated regression in panel data. Adv Econom, 15: 179222.

Karakurt I, Aydin G, Aydiner K. 2012. "Sources and mitigation of methane emissions by sectors: a critical review." Renewable energy 39(1): 40-48.

Khan MTI, Ali Q, Ashfaq Mç 2018. The nexus between greenhouse gas emission, electricity production, renewable energy and agriculture in Pakistan. Renewable Energy, 118, 437-451. doi:https://doi.org/10.1016/j.renene.2017.11.043

$\mathrm{Ke} \mathrm{X,} \mathrm{Lu} \mathrm{Y,} \mathrm{Conrad} \mathrm{R.} \mathrm{2014.} \mathrm{"Different} \mathrm{behaviour} \mathrm{of}$ methanogenic archaea and Thaumarchaeota in rice field microcosms." FEMS microbiology ecology 87(1): 18-29.

Kummu M, De Moel H, Porkka M, Siebert S, Varis O, Ward PJ. 2012. Lost food, wasted resources: Global food supply chain losses and their impacts on freshwater, cropland, and fertiliser use. Science of The Total Environment, 438: 477-489.

Levin A, Lin C, Chu C. 2002. Unit root tests in panel data: asymptotic and finite sample properties. JEconom., 108, 124.

Liu J, Fritz S, Van Wesenbeeck Cfa, Fuchs M, You L, Obersteiner M, Yang HA. 2008. Spatially explicit assessment of current and future hotspots of hunger in Sub-Saharan Africa in the context of global change. Global and Planetary Change, 64(3): 222-235.

Lobell DB. 2014. Climate change adaptation in crop production: Beware of illusions. Global Food Security, 3(2): 72-76.

Lütkepohl H, Saikkonen P. 1997. Impulse response analysis in infinite order cointegrated vector autoregressive processes. Journal of Econometrics, vol. 81, no. 1, 127-157.ss.

Mackinnon J. 1996. Numerical Distribution Functions for Unit Root and Cointegration Tests. J. Applied Econm., 11: 601618.

Maddala G, Shaowen W. 1999. Comparative study of unit root tests with panel data and a new simple test. Oxf Bull Econ Stat, 61, pp. 631-652.
Mehmood B, Feliceo A, Shahid A. 2014. What Causes What? Aviation Demand and Economic Growth in Romania: Cointegration Estimation and Causality Analysis, Romanian Economic and Business Review, 9(1): 21-34.

NCCC. 2012. National Coordination Committee on Climate Change (NCCC) Second National Communication on Climate Change of the People's Republic of China, China Planning Press, Beijing (2012).

Özsoy C. 2009. The Analysis with VAR model of relationship between education and economic growth in Turkey. Journal of Knowlede Economy \& Knowledge Management 4(1): 7183. (in Turkish)

Pachauri RK, Allen MR, Barros VR, Broome J, Cramer W, Christ R, Church JA, Clarke L, Dahe Q, Dasgupta P. 2014. Climate change 2014: synthesis report. Contribution of Working Groups I, II and III to the fifth assessment report of the Intergovernmental Panel on Climate Change, IPCC.

Park J. 1992. Canonical Cointegrating Regressions. Econometrica, 60: 119-143.

Pedroni P. 2000. Fully-modified OLS for heterogeneous cointegrated panels, Non-stationary panels, panel cointegration, and dynamic panels. In B. Baltagi (Ed.), Advances in Econometrics (pp. 93-130). Amsterdam; New York and Tokyo: Elsevier Science.

Pedroni P. 2001. Purchasing power parity tests in cointegrated panels. The Review of Economics and Statistics, 83(4): 727731

Peker K, Kan M, Nadeem M. 2019. Corporate governance of climate change adaptation. J. Glob. Innov. Agric. Soc. Sci., 7 (1): $1-5$

Perron P. 1989. "The Great Crash, the Oil Price Shock, and the Unit Root Hypothesis", Econometrica, 57/6: 1361-1401.

Perron P, Vogelsang TJ. 1993. A note on the asymptotic distributions of unit root tests in the additive outlier model with breaks. Brazilian Review of Econometrics, 13(2): 8-201.

Ripple WJ, Smith P, Haberl H, Montzka SA, Mcalpine C, Boucher DH. 2013. Ruminants, climate change and climate policy. Nature Climate Change, 4, 2.

Tao F, Hayashi Y, Zhang Z, Sakamoto T, Yokozawa M. 2008. Global warming, rice production, and water use in China: Developing a probabilistic assessment. Agricultural and Forest Meteorology, 148(1): 94-110.

Tao L, Toshihiro H, Xinyou Y, Yan Z, Kenneth B, Myriam A, Bas B. 2015. Uncertainties in predicting rice yield by current crop models under a wide range of climatic conditions. Global Change Biology, 21(3): 1328-1341.

Tari R. 2010. Econometrics (6b.). Kocaeli Province: Umuttepe Publishing. (in Turkish).

Van Oort PAJ, Zwart SJ. 2018. Impacts of climate change on rice production in Africa and causes of simulated yield changes. Global Change Biology, 24(3): 1029-1045.

Wang W, Koslowski F, Nayak DR, Smith P, Saetnan E, Ju X, Guo L, Han G, de Perthuis C, Lin E, Moran D. 2014. "Greenhouse gas mitigation in Chinese agriculture: Distinguishing technical and economic potentials." Global Environmental Change 26: 53-62.

Waheed R, Chang D, Sarwar S, Chen W. 2018. Forest, agriculture, renewable energy, and $\mathrm{CO}_{2}$ emission. Journal of Cleaner Production, 172, 4231-4238. doi:https://doi.org/10.1016/j.jclepro.2017.10.287 